\title{
Managerial accounting in the system of payments with enterprise buyers
}

\author{
(Supervised by: PhD in Economics, prof. Lehenchyk S.F.)
}

Today, in the period of global changes in different spheres of social activity, the issue of managerial accounting in the system of payments with buyers is actual enough as the efficiency of management of enterprise economic activity to a great extent depends exactly on the information resources of managerial accounting.

The managerial accounting in the system of payments with buyers is adjusted on the implementation of enterprise strategies, that is the construction of administrative accounting depends on the strategy of market scope. There is a necessity to make the decision about how many places for selling products should be opened on a certain geographical territory to satisfy the necessities of present and potential clients of a special purpose group in products, commodities and services. The system of tasks of administrative accounting in the system of payments with buyers is formulated, that allows to unite all the information about the products sold, will do the information integral and will enable users, in particular, the leader of an enterprise, to a great extent to take the opportunity to get the complete information on the state of calculations with buyers and to make administrative decisions correctly in order to avoid complicated and contradictory situations with buyers. The paper determines the directions for further researches in relation to the development of issues, which have direct regard to the buyers of purchase-sale contractual relations.

Keywords: accounting; managerial accounting; payments with buyers; amount of products sold; debt.

Statement of the problem. The formation of new market relations causes an objective necessity in new approaches for the management of payments with buyers and appearance of new information needs in enterprise management. One way of restructing accounting is to provide entities with information resources of managerial accounting. The enterprise independently works out the system and forms of inner economic (managerial) accounting, reporting and inspection of economic operations [9].

The managerial accounting in the system of payments with buyers is adjusted on the implementation of enterprise strategies, that is the construction of administrative accounting depends on the strategy of market scope. There is a necessity to make the decision about how many places for selling products should be opened on a certain geographical territory to satisfy the necessities of present and potential clients of a special purpose group in products, commodities and services.

There are three main market scope strategies - the first one is an intensive distribution according to which goods are distributed among the biggest amount of sale places; the second one is a selective distribution when goods are distributed among the limited amount of sale places on a certain geographical territory; the third one is an exclusive distribution when goods are distributed only on one place of a certain geographical territory. It is clear that the amount of capital necessary for creating the channel, which is owned solely and uses the intensive distribution, is extremely important.

Having chosen a definite segment, the enterprise should determine for itself how to penetrate the market and get competitive advantages. For this it is necessary to research the positions of all the competitors available at the market and determine an own place after positioning the goods.

The aim of activity for every enterprise is to get the maximum possible profit and maintenance of financial stability of the enterprise. It is a pity but most enterprises do not have the constant and grounded policy of making decisions about the management of payments with buyers. This can cause financial loses or failure to get a part of profit.

Nowadays, significant tasks for the managerial accounting in the system of payments with buyers are:

- formation of analytical accounts for each buyer and for each kind of products;

- use of forms of payments with buyers;

- assessment of quality and timeliness of payments with buyers;

- discharge of contracts with buyers;

- determination of results after the sale of innovative objects of enterprise operation;

- formation of results from organic output;

- assessment of financial results about enterprise buyers;

- determination of sale effectiveness assessment or the assessment of reprocessing with further sale;

- formation of managerial reporting about payments with buyers.

The importance of studying these issues is increasing for every enterprise under market conditions. 
Analysis of the recent researches and publications. The lack of methods for the managerial accounting in the system of payments with buyers and experience of its practical use in the activity of domestic entities can be connected with the factor of indeterminacy and the lack of uniformity to the very determination of its accounting system.

P.M. Garasym, G.P. Zhuravel', and P.Ja. Homyn consider it is unbelievable that the due control over the payments with buyers can be ensured only with the help of financial accounting, though most authors who write about the issues of managerial accounting, do not pay any attention to the payments with buyers. At the same time, even the accounting of payments with buyers, just indirectly, but also influences the formation of financial results, and it is done rather extremely to be ignored in the managerial accounting [2].

Another scientist Je.M. Zaremba states that the managerial accounting covers all the types of accounting and non-accounting information, which is used for immediate management of phenomena and processes in relation to the segments and centers of responsibility, so, in his opinion it is necessary to include operative inspection and the analysis of payments with buyers and enterprise money flows in the managerial accounting [4].

It is difficult for some scientists to provide a single answer about the efficiency of the managerial accounting in the system of payments with buyers at enterprises. For instance, for determining the efficient conducting the managerial accounting in the system of payments with buyers, S.O. Kucherkova suggests to carry out the inner economic reporting, which will provide timely receiving information about the products sold and payments with buyers using primary accounting. This reporting may consist of several divisions, namely, the manufacture of products, the sale of products and the results after the sale of products [5].

In spite of considerable contribution of researchers for the development of the managerial accounting in the system of payments with buyers, it is necessary to indicate that the issues of improving the managerial accounting in the system of payments with buyers are not studied yet enough.

Purpose of the article. The article aims at the study of the theoretical aspects of management of the managerial accounting in the system of payments with buyers and also the development of suggestions about its improvement.

Principal research results. The essence of managerial accounting, according to P. Kaplan, includes the following:

1) providing all the levels of management with data, necessary for making management decisions and

2) producing information, which is the means of communication at the enterprise. S.F. Golov considers that managerial accounting is the process of finding, changing, accumulation, analysis, preparation, interpretation and transmission of the information, which is used by a managerial team for planning, assessment and inspection at the enterprise and for providing appropriate accountable use of resources [3, p. 246].

Managerial accounting as the information system of economic activity management is the integral mechanism of information exchange, which acts in three forms:

- from a manager to subordinates about the tasks which are set before a division or an enterprise, and, on the contrary, from subordinates to management about the fulfilment of tasks in a real time;

- managerial reports that describe a general state of fulfilment of the planned task;

- informal discussion of the business state and the fulfilment of the task set.

Managerial accounting is not only gathering and registration of information, but also its analysis and assessment in order to obtain the data based on which it is possible to manage an enterprise, first and foremost, efficient.

The aim of managerial accounting conducting is providing the users with complete, honest and fair information about the financial state and the results of enterprise activities for making decisions. For this it is necessary to have all sufficient information about the facts of enterprise economic activity in relation to kinds of products, the centres of responsibility, the places of shipping, or personal orders.

According to the aim of managerial accounting in the system of payments with enterprise buyers we are going to characterize the above-mentioned tasks:

1. To obtain reliable data of different levels of detail about the payments with buyers in an accounting enterprise we will divide them into two groups of accounts: synthetical and analytical. So, the synthetical, or, as they are also called, united accounts provide the generalized data about economically homogeneous groups of buyers. According to the principle of unitary monetary measurer, the information about the buyers that is included in the synthetical accounts has only monetary assessment, which enables to get only the generalized data about the payments with enterprise buyers.

Analytical accounts are used for detailing the information about the payments with buyers who are registered on the synthetical account. Analytical accounts are opened for every buyer in relation to kinds of buyers, products, market segments, forms of payment, terms of payment, etc.

2.The research of calculation relations with buyers showed that while conducting operations the most important is the right selection of the payment form and their accounting providing as it enables counteragents to 
decrease expenses and losses of non-execution of contract obligations by the opposite side. Cash, noncash (clearing) and barter forms of payment are distinguished.

Under market conditions it is necessary to perform the selection of the payment form due to the following criteria: reliability, inspection, computerization of documents, acceleration of circulation of funds, minimum labour consuming for payment operations. Clearing operations meet these criteria the most because noncash ones belong to the progressive forms of payment.

The current legislation of Ukraine provides enterprises with the possibility to select free the forms of clearing operations among enterprises according to such different factors as the type of a buyer (wholesale, exchange, retail, independent, regulated, fixed), the type of products, the amount of sale, the amount of payment for goods, etc. At the same time, clearing operations have a big selection among the kinds of payment tools for enterprise relations, namely, payment orders, payment claim-orders, payment claims, calculation cheques, letters of credit, promissory notes, remote control systems, mutual debt payments, barter operations, the claim right concession.

It is undoubtedly, that none of the payment forms creates additional funds. So, in market conditions it is necessary to apply such a form, which could guarantee timely and complete income of funds on the account of produce manufacturer, could provide appropriate level of mutual and bank inspection over the fulfilment of contract obligations.

3. The fulfilment of conditions of pay relations provide regular supply, continuity in production, timeliness of shipment and sale of products (works, services). Obtaining payments from buyers is one of the main sources of money income at an enterprise, that is why the proceeds from sale is the only means for paying off all the kinds of credit indebtedness. Money income from sale determines the possibilities of the enterprise concerning paying off the debts to creditors. As a rule, the most part of a debtor obligation is formed as debts of buyers. To bring into contractual relations with buyers where the relations provide timely and sufficient money income to transact payments to creditors is the principal task for the management of debtor obligation move. We calculate the timeliness of payments with the help of debtor obligation amount and the amount of reserve of doubtful debts.

So, as a whole, the efficiency of enterprise activity depends on the quality of assessment of payments with buyers.

4. Under competitive conditions an enterprise can lose its sale markets because of the failure in due organization of contracts that can cause decrease in production. The main document regulating relations between economic entities is a purchase and sale contract where the type of contract operation, the object of operation, basic conditions of delivery, quantity, the price of goods, the terms of delivery, the order of payments are determined. That is why the principal task of checking of fulfilment of contractual relations with buyers is the clarification of lawfulness and solid reasons for concluding of contracts, the execution of their conditions and the check-up of realization of mutual payments on the operations of products sale to buyers. During the check-up special attention is paid to the possible cases of purposeless concluding of contracts.

The fulfilment of contractual obligations concerning the delivery of products to buyers is checked up under the provisions of operative accounting registers (books, journals, cards), which are conducted according to quantity, assortment, quality, the term of delivery, the rhythmicity of their shipment to buyers.

5. To be solvent an enterprise has to meet the needs of consumers. That is why the determination of more effective range of goods than competitors have, allows to decrease the expenses and to increase the profit and as a result, to increase the economic stability of the enterprise. The formation of the range of goods should include:

- the choice of the products according to consumers' inquiry;

- providing the competitiveness of products:

- determination of strategies according to the life style stage of products;

- the policy of innovations;

- the determination of trade mark, pack and service;

- positioning of goods [1].

The optimization of new types of products (the range of products), which are simultaneously sold at the market but differ with their level of novelty, make it possible to guarantee the enterprise relatively stable conditions of sale amounts, the covering of costs and the level of profit. To decrease the amounts of buyers' indebtedness to enterprises one should put out more strict conditions for the sale and payment of products. The amount of necessity of products is determined according to the consumers' demand data.

6. Currently, the demand on organic products is increasing in Ukraine, and this is a favorable factor. Selling the organic products at the market, the enterprise must guarantee the highest quality indices for winning a buyer's credit and strong stabilizing the market. 
The immediate significance at the relations of payment for the organic products belongs to:

- the price, which is the important regulator of interaction of entities of market relations and builds sellers' income and buyers' expenditures. The prices of the organic producer are rather unstable depending upon the harvest and export-import operations;

- the quality, that is, their ecological clearness and the safety for environment are also the main factors of competitiveness for agricultural production [9].

The sale of organic products will essentially influence upon positioning of Ukraine in the world, improve the financial situation of enterprises as incomes from selling such kind of products are considerably higher than from selling usual products.

7. The information about the general financial result of enterprise production and economic activity is shown with enterprise income. The most important index of total amount of income is the income from the sale of products and its size is built under the influence of the payments with buyers. A number of factors affect the income from the sale of products; we single out such factors as: the sale amount, the structure of products, selling prices on raw materials, materials, fuel, tariffs on energy and transportation, the level of costs for material and labor resources.

However, it is significant to have the information about the place not only of the amounts of the activity, but also about the place of every buyer in the financial result as each buyer can influence the formation of the enterprise results differently.

8. Managerial accounting helps make the decision connected with the possibility of sale of products on the certain stage of their manufacture or continuation of their processing to obtain an extra profit. The extra processing of products (or addition to the spectrum of services) can provide new features or the functions of products (or flexibility or quality of services) and their sale at a higher price. For example, an enterprise can take into account the alternative to sale products or to direct a part of them to reprocessing in order to manufacture a new kind of products. Another option for decision "to sale or to keep on their processing" is the decision about faulty products saying "to sell them with a discount or remove a defect and sell the products at ordinary price.

9. Planning sale policy, the enterprise management, first and foremost, should choose the strategy for the policy directing in what way the system of selling has to be arranged, namely, via own or dealer's net, the types of resellers via who the movement of goods should be realized.

According to the location places of the principal sale markets and buyers of products (goods, works, services) of an enterprise we distinguish a geographical sale segment (a segment is a certain kind of products, a direction or sale). The enterprise independently determines the level of detail of geographical regions taking into account the necessity to open essential information.

The existing sale channels involve three main sale methods:

- direct when a producer sells products directly to buyers;

- side when the sale is arranged via independent dealers;

- combined when the sale is carried out via the organization with the joined capital of a firm-producer and an independent firm.

Enterprises that mainly solve the same task of fast obtaining of cash, create their own trade net, stores at the gateway of an enterprise, firm stores, etc. Undoubtedly, it gives an opportunity to economize something for the payment of intermediaries' services.

The income from the sale and the financial results of geographical sale segments are determined according to the location place of the main enterprise sale markets. We mean contractual (more constant) sales of products to other regions, which the enterprise considers to single out as a segment.

The information about the priority geographical reporting segments is described more detailed in the reporting. The indices about the extra reporting geographical segments are included in the Addition to the Notes about the annual financial reporting «Information on segments» in issue 3.

To provide the complete information necessary for making managerial decisions about the payment situation with buyers to optimize their amounts and provide timely paying off the debts, namely, to build the effective systems of inspection of the movement of payments with buyers, the special control of the indebtedness, the term to pay for which has not come yet, and also the control of the indebtedness, which was not paid off on time, the enterprise may make a tally sheet monthly (tabl. 1).

Studying the payments with buyers, the problems of non-payments, it is necessary to remember that this can result in increasing economic risks while carrying out the payments among economic entities.

So, the process of managerial accounting of payments with buyers is the system of information providing about payment relations and the measures connected with solving the tasks about the payments with buyers for making managerial decisions. The managerial accounting has to provide the full operative information not only about actual indebtedness of buyers before the enterprise, that is possible according to the data of financial accounting, but also about the possibility to pay off the debt on definite terms. 
ISSN 1994-1749. 2017. Bun. 3 (38).

Проблеми теорії та методології бухгалтерського обліку, контролю і аналізу

Tally sheet about the state of payments with enterprise buyers in September 2017

\begin{tabular}{|c|c|c|c|c|c|c|c|c|c|}
\hline \multirow[t]{2}{*}{ № } & \multirow{2}{*}{ Buyer's name } & \multirow{2}{*}{$\begin{array}{l}\text { Form of } \\
\text { payments }\end{array}$} & \multicolumn{2}{|c|}{ Term of payments } & \multirow{2}{*}{ Reason of debt } & \multicolumn{4}{|c|}{$\begin{array}{c}\text { Amount of debt } \\
\text { hrv. }\end{array}$} \\
\hline & & & $\begin{array}{l}\text { according } \\
\text { to contract }\end{array}$ & actually & & $\begin{array}{l}\text { according } \\
\text { to contract }\end{array}$ & $\begin{array}{c}\text { delayed } \\
\text { part }\end{array}$ & fine & total \\
\hline 1 & $\mathrm{PE} \ll$ Hope» & $\begin{array}{c}\text { clearing } \\
\text { operations }\end{array}$ & $\begin{array}{c}04.09 . \\
2017\end{array}$ & $\begin{array}{l}18.09 . \\
2017 \\
\end{array}$ & $\begin{array}{l}\text { delay of } \\
\text { payment }\end{array}$ & 15000 & 5000 & 500 & 15500 \\
\hline 2 & $\begin{array}{c}\text { LLC } \\
\text { «Breathe» }\end{array}$ & $\begin{array}{c}\text { clearing } \\
\text { operations }\end{array}$ & $\begin{array}{c}05.09 . \\
2017\end{array}$ & $\begin{array}{c}05.09 . \\
2017\end{array}$ & $\begin{array}{l}\text { delay of } \\
\text { payment }\end{array}$ & 7000 & - & - & 7000 \\
\hline 3 & $\begin{array}{c}\text { PSC } \\
\text { «Kyyivbread» }\end{array}$ & $\begin{array}{c}\text { clearing } \\
\text { operations }\end{array}$ & $\begin{array}{c}06.09 . \\
2017\end{array}$ & $\begin{array}{l}19.09 . \\
2017\end{array}$ & $\begin{array}{l}\text { delay of } \\
\text { payment }\end{array}$ & 17500 & 2500 & 250 & 17750 \\
\hline
\end{tabular}

Conclusions and prospects for further researches. In conclusion we would like to say that the researched tasks of the managerial account in the system of payments with buyers will considerably unite all the information about the sale of products, will make it integral and enable users, an enterprise manager, in particular, to get the complete information about the state of payments with buyers and make managerial decisions correctly to avoid complicated and contradicting situations with buyers.

Based on the above-mentioned, we consider that the development of the issues related directly to the buyers of contractual relations of purchase-sale can be the perspective direction of further scientific researches. This will contribute to the improvement of relations with buyers for more effective enterprise activity.

\section{Список використаної літератури:}

1. Балабанова Л.В. Маркетинг підприємства : навч. посібник / Л.В. Балабанова, В.В. Холод, І.В. Балабанова / Мін-во освіти і науки України ; Донецк. нац. ун-т економіки і торгівлі ім. М.Туган-Баранівського ; Школа Маркетингового менеджменту. - Донецьк : ДонНУЕТ, 2010. - 599 с.

2. Гарасим П.М. Фінансовий, управлінський та податковий облік / П.М. Гарасим, Г.П. Журавель, П.Я. Хомин. Тернопіль : ТНЕУ, 2003. - 522 с.

3. Голов С.Ф. Бухгалтерський облік в Україні: аналіз стану та перспективи розвитку : монографія / С.Ф. Голов. К. : ЦУЛ, 2007. - 522 с.

4. Заремба С.M. Обліково-аналітичне забезпечення інтегрованого бухгалтерського обліку грошових потоків підприємства / Є.М. Заремба // Економіка. Фінанси. Менеджмент: актуальні питання науки і практики. - 2015. № 2. - C. 46-52.

5. Кучеркова С.О. Покращення аналітичного обліку реалізації продукції та розрахунків з покупцями / С.О. Кучеркова // Економічні науки. Серія : Облік і фінанси. - 2012. - Вип. 9 (2). - С. 223-228.

6. Петрук О.М. Гармонізація національних систем бухгалтерського обліку : монографія / О.М. Петрук. Житомир : ЖДТУ, 2005. - 420 с.

7. Про бухгалтерський облік та фінансову звітність в Україні : закон України : від 16.07.1999 р. : № 996-XIV / Верховна Рада України [Електронний ресурс]. - Режим доступу : http://zakon4.rada.gov.ua/laws/show/996-14.

8. Цал-Цалко Ю.С. Управлінський облік : підручник / Ю.С. Цал-Цалко, Ю.Ю. Мороз, Н.І. Цегельник. Житомир : ПП «Рута», 2015. - 632 с.

9. Цегельник H.I. Стан виробництва органічної продукції в Україні та ії потенційні покупці / Н.I. Цегельник // Органічне виробництво і продовольча безпека : зб-к мат-лів доп. учасн. II Міжнар. наук.-практ. конф. Житомир : Полісся, 2014. - С. 522-526.

10. Шевчук К.В. Роль управлінської звітності в обліково-інформаційній системі підприємства та особливості іiі формування / K.B. Шевчук // Науковий вісник Ужгородського національного університету. Серія : Міжнародні економічні відносини та світове господарство. - 2016. - Вип. 6 (3). - С. 137-140 [Електронний pecypc]. - Режим доступу : http://nbuv.gov.ua/UJRN/Nvuumevcg_2016_6\%283\%29_35.

\section{References:}

1. Balabanova, L.V., Holod, V.V. and Balabanova, I.V. (2010), Marketyng pidpryjemstva, navch. posibnyk, Min-vo osvity i nauky Ukrai'ny, Doneck. nac. un-t ekonomiky i torgivli im. M.Tugan-Baranivs'kogo, Shkola Marketyngovogo menedzhmentu, DonNUET, Donec'k, 599 p.

2. Garasym, P.M., Zhuravel', G.P. and Homyn, P.Ja. (2003), Finansovyj, upravlins'kyj ta podatkovyj oblik, TNEU, Ternopil', $522 \mathrm{p}$.

3. Golov, S.F. (2007), Buhgalters'kyj oblik v Ukrai'ni: analiz stanu ta perspektyvy rozvytku, monografija, CUL, Kyi'v, 522 p.

4. Zaremba, Je.M. (2015), «Oblikovo-analitychne zabezpechennja integrovanogo buhgalters'kogo obliku groshovyh potokiv pidpryjemstva», Ekonomika. Finansy. Menedzhment: aktual'ni pytannja nauky i praktyky, No. 2, pp. 46-52. 
5. Kucherkova, S.O. «Pokrashhennja analitychnogo obliku realizacii' produkcii' ta rozrahunkiv z pokupcjamy», Ekonomichni nauky, Cerija Oblik i finansy, Vol. 9 (2), pp. 223-228.

6. Petruk, O.M. (2005), Garmonizacija nacional'nyh system buhgalters'kogo obliku, monografija, ZhDTU, Zhytomyr, $420 \mathrm{p}$.

7. Verhovna Rada Ukrai'ny (1999), «Pro buhgalters'kyj oblik ta finansovu zvitnist' v Ukrai'ni», zakon Ukrai'ny, vid 16 lypnja, N 996-XIV, available at: http://zakon4.rada.gov.ua/laws/show/996-14

8. Cal-Calko, Ju.S., Moroz, Ju.Ju. and Cegel'nyk, N.I. (2015), Upravlins'kyj oblik, PP «Ruta», Zhytomyr, 632 p.

9. Cegel'nyk, N.I. (2014), «Stan vyrobnyctva organichnoi' produkcii' v Ukrai'ni ta i'i' potencijni pokupci», Organichne vyrobnyctvo i prodovol'cha bezpeka, zb-k mat-liv dop. uchasn. II Mizhnar. nauk.-prakt. konf., Polissja, Zhytomyr, pp. 522-526.

10. Shevchuk, K.V. (2016), «Rol' upravlins'koi' zvitnosti v oblikovo-informacijnij systemi pidpryjemstva ta osoblyvosti i'i' formuvannja», Naukovyj visnyk Uzhgorods'kogo nacional'nogo universytetu, Serija Mizhnarodni ekonomichni vidnosyny ta svitove gospodarstvo, Vol. 6 (3), pp. 137-140, available at: http://nbuv.gov.ua/UJRN/Nvuumevcg_2016_6\%283\%29_35

Цегельник Ніна Іванівна - асистент кафедри бухгалтерського обліку, оподаткування та аудиту Житомирського національного агроекологічного університету.

Наукові інтереси:

- облік, аналіз та аудит розрахунків з покупцями підприємства.

E-mail: n.i.norinchak@mail.ru. 